\title{
Educational Administrators' Facing COVID-19 Measures In Paraguay
}

\author{
Valentina Canese \\ Universidad Nacional de Asunción \\ Jessica Amarilla \\ Universidad Nacional de Asunción
}

\begin{abstract}
Around the world COVID-19 has forced governments to take measures that have so far affected education systems, in various ways. Face-to-face interactions have been disrupted in around $70 \%$ of educational institutions as per reported by UNESCO (2020). Due to the pandemic, authorities in Paraguay adopted early measures to prevent the spread of the virus which in turn have affected educational institutions greatly. This article reports an analysis of educational administrators' institutional perspectives in light of the challenges presented by quarantine measures and considering elements such as infrastructure and access to technology, teacher training, student and parent limitations. A mixed quan-qual approach was followed using closed and open-ended questionnaires. The sample included 110 educational administrators from public and private institutions at all levels throughout the country. Results of this study report that when the quarantine started, educational institutions had difficulty migrating to distance learning. Such difficulties were: limited access to the Internet, poor training in the use of and access to educational ICT. Opportunities to invest in infrastructure, train teachers and rethink education were also noted. These results demonstrate the need for greater and better access to educational technologies by the main educational actors in the country to guarantee equal academic opportunities.
\end{abstract}

Keywords: educational institutions, COVID-19, educational administrators, challenges, opportunities

\section{Introduction}

The pandemic caused by COVID-19 has disrupted education around the world forcing schools and universities to stop face-to-face classes affecting around 1.2 billion students worldwide (UNESCO, 2020a). This decision stems from measures imposed by the World Health Organization (WHO) to control the rapid spread of the virus (WHO, 2020). Views on the disruption of education vary from place to place, some see it as a short-term crisis with no real change coming to schools and others see it as an opportunity to rethink education (Zhao, 2020). One thing is certain though, the pandemic impact is unprecedented and will bring short term and long-term costs (World Bank Group, 2020). 
Considering the case of Paraguay, the Ministry of Public Health and Social Welfare imposed quarantine measures immediately after the first case of COVID-19 was reported forcing all students to stay home from March 10 (MSPBS, 2020). The Ministry of Education (MEC) then adopted distance learning strategies for the continuity of education implementing the "Your School at Home" platform with resources for teachers, parents and students (MEC, 2020). Moreover, higher education institutions also turned to online learning following the guidelines of the National Council of Higher Education (CONES). As of August 20, the National Council of Higher education has approved the migration from traditional to virtual classes of 2,453 academic programs (CONES, 2020).

The quarantine measure affecting school closures was to be in place for a period of 15 days; yet, as the pandemic spread, the Ministry of Education opted for extending this measure until the end of the school year in December 2020 (MEC, 2020). The swift move to distance education has been examined critically by many, not only in Paraguay, but also by researchers abroad (Wehrle, 2020). The negative effects that have become evident with the implementation of massive virtual learning strategies include the rise in school dropouts (Sanz, Sainz \& Capilla, 2020), the growth of inequality in education (CEPAL, 2020; Cifuentes-Faura, 2020; Monasterio \& Briceño, 2020), and the overall interruption of education for students as well as higher economic costs for their families (UNESCO, 2020b).

Due to the current situation with COVID-19 and the measures taken to address it, and considering there is little information in regards to the response of all educational actors including students, teachers, parents and administrators, this study seeks to shed a light on their perspectives in light of this situation. This article presents an analysis of educational administrators' institutional perspectives in light of the challenges presented by quarantine measures and considers elements such as infrastructure and access to technology, teacher training, student and parent limitations.

A mixed quan-qual approach was used through the use of questionnaires adapted from Wozney, Venkatesh and Abrami (2006) to the conditions presented by COVID-19 which included closed and open questions and was followed by focus groups with voluntary participants. The study was carried out during the fourth to sixth weeks of suspension of academic activities (end of April and beginning of May) and the sample included 110 educational administrators from public, private and charter institutions at all educational levels throughout the country with the exception of Alto Paraguay. Most of the educational administrators who participated in the survey (71\%) live in Asunción, the capital city, and the Central Department, while the others come from the remaining departments in the country.

The questionnaire consisted of 32 questions, including five that were open ended and provided an insight on the challenges, opportunities and measures resulting from the measures taken by the government due to COVID-19. The questionnaire was administered through an online survey tool and distributed by digital means such as mailing lists, social networks such as Facebook and WhatsApp groups. The data collected were analyzed using univariate descriptive statistics (counts and percentages through statistical tables). For the manipulation and ordering of the data, the electronic Excel spreadsheet was used, while for the statistical analysis the 
statistical software R (R Core Team, 2020) was used.

The qualitative data was analyzed using qualitative content analysis through coding which resulted in three main analytical categories: "difficulties or challenges," "opportunities," and "measures adopted." Within these larger categories we were able to identify sub-categories related to financial aspects, connectivity, digital migration, community response, uncertainty related to government guidelines, mental wear and quality among the difficulties. In regards to the opportunities, we were able to identify subcategories such as opportunities for training, for investing in infrastructure and other school needs, for rethinking the whole system and for achieving digital migration.

Table 1. Qualitative analytical categories and sub-categories.

\begin{tabular}{|l|l|l|}
\hline Challenges & Opportunities & Measures adopted \\
\hline Access & Training & Continue \\
\hline Financial & Infrastructure investment & Adapt \\
\hline Digital Migration & Rethinking system & According to possibility \\
\hline Community & Digital Migration & Prioritize health \\
\hline Uncertainty & Teleworking & Cancelling classes \\
\hline Guidelines & & Curriculum \\
\hline Mental wear & & Financial Assistance \\
\hline Quality & & Printed material \\
\hline
\end{tabular}

Finally, regarding the measures adopted in the different institutions, sub-categories included positions such as continue as we are doing, adapt to the situation according to possibilities, prioritizing health, cancelling classes, work on curriculum, providing financial assistance and printed material to families as well as support for community members (See Table 1). The following results will be organized according to these categories.

\section{RESULTS}

According to the responses received, $62 \%$ of the educational administrators in the study work in public educational institutions and the remaining in private and charter institutions; and most of them work at the basic and middle school level of the national education system (grades K-12). Most institutions have an enrollment that ranges from 100 to over 500 students and employ over 40 people within their school staff. The study results consider the challenges faced, the measures adopted and opportunities presented by school administrators in light of quarantine measures and the implementation of ICT for the delivery of education.

\section{Challenges presented by the situation}

First of all, an important challenge was teacher training provided by education institutions in Paraguay. In this case, $65 \%$ of educational administrators responded that their teachers did not receive any training in the use of technological tools before the quarantine began. However, with the quarantine already declared, $50 \%$ of the directors indicated that 
the teachers who work in their respective educational institutions have received special training on virtual classes and the different distance education tools available. In this sense, 45 of the 70 institutions that stated that their teachers did not receive training in the use of technological tools before the quarantine, still did not receive it with the implementation of the measures adopted by the government to face the crisis caused by the COVID-19 (see Table 2).

Table 2. Teacher training before and after quarantine was declared.

\begin{tabular}{||l|l|l|l|l|}
\hline \multicolumn{2}{|c|}{} & \multicolumn{3}{l}{$\begin{array}{l}\text { Teacher training on virtual classes once quarantine } \\
\text { was declared }\end{array}$} \\
\cline { 2 - 5 } \multicolumn{2}{|c|}{} & Yes & No & Total \\
\hline \multirow{2}{*}{$\begin{array}{c}\text { Teacher training on } \\
\text { virtual classes before } \\
\text { quarantine }\end{array}$} & Yes & 28 & 9 & 37 \\
\cline { 2 - 5 } & No & 26 & 45 & 71 \\
\cline { 2 - 5 } & Total & $\mathbf{5 4}$ & $\mathbf{5 4}$ & $\mathbf{1 0 8}$ \\
\hline
\end{tabular}

School administrators also mentioned financial factors as an important obstacle within their institutions. Firstly, the challenge of maintaining all job positions was also reported. In this case, $13 \%$ of managers mentioned that their institution did not keep their full staff weeks after the COVID-19 quarantine was declared, with private institutions being the most affected by this fact. According to the management participants, on average, 11 people were removed from their jobs when the quarantine came into effect. Some managers have even indicated that up to 35 people were left without work in their educational institutions. Results also indicate that in $22 \%$ of the institutions that participated in the study, employee salaries were reduced or underwent some temporary modification. Secondly, $60 \%$ of the administrators responded that their institutions were offering special discounts or some other economic arrangement with students and parents to alleviate the difficult situation experienced in an environment of total uncertainty caused by the pandemic (See Table 3).
Table 3. School offer of special discount according to institution type.

\begin{tabular}{|l|l|l|l|}
\hline Institution type & \multicolumn{3}{|l|}{$\begin{array}{l}\text { Special discount is } \\
\text { offered }\end{array}$} \\
\cline { 2 - 4 } & Yes & No & Total \\
\hline Public & 7 & 45 & 52 \\
\hline Private & 24 & 8 & 32 \\
\hline Charter/Other & 6 & 2 & 8 \\
\hline Total & $\mathbf{3 7}$ & $\mathbf{5 5}$ & $\mathbf{9 2}$ \\
\hline
\end{tabular}

Moreover, in the qualitative responses participants indicated that financial difficulties were central to consider in regards to both community 's access and the continuity of private educational institutions. The uncertainty generated by the suspension of in-person activities, especially in regard to financial concerns, resulted in several administrator's noting their grave concern in their capacity to continue providing educational services if parents were unable to pay their fees; in their own words: "they do not want to pay." Thus, one of them noted the following:

We are in a state of total uncertainty. 
We do not have a parameter to guide us; we are between a rock and a hard place. We lose about $20 \%$ of our students monthly. We are obligated to pay salaries, social security does not wait for us because there are basic services as well as the internet to pay even more so, and everything else. Parents demand a $50 \%$ discount but we know that even if we do this, only $20 \%$ will pay because of the lack of work; in a nutshell, many more things.

Participants also referred to the problems related to access to technology and connectivity by all members of the educational community, especially parents and students referring to this as difficulties with "connection to the internet and access to technological equipment." Some indicated that "most families have only one smartphone device and there are usually several children who have to do schoolwork;" or, that there is "low connectivity to the internet... [and] the lack of skills in the use of technology among teachers, administrative staff and services."

As can be seen in this quote, uncertainty is another issue that was highlighted by all members of the educational community, especially administrators who have to mediate between the measures taken by the government and other educational actors. In this regard, several of them referred that the guidelines presented by both the MEC and the CONES were not clear at the beginning and that they were "left with the uncertainty of how to carry out the "virtual migration," which they also referred to as one of the main difficulties at the beginning of the pandemic. The process of "virtual migration" involves bringing all educational and administrative processes into a format for which the institutions were not prepared in various ways. Among them is the technological infrastructure, such as having the right platforms that can serve students. Also, part of this migration involves the following subcategory referring to community members who were not prepared for it.

Administrators noted that the lack of training is one of the most important difficulties found in relation to not only to the institutions' staff, but also to the students and their parents. As seen in the quantitative results above, educators admit their limitations in transferring their lessons to a distance mode. One administrator noted that

It is absurd to want to implement virtual teaching and learning overnight. In this moment, teachers are not prepared to conduct virtual education, they don't have the conditions, or the tools, and neither the necessary strategies to lead this educational modality. Teachers need to know and be convinced about virtual education to be effective in their professional field. They cannot give what they don't have.

Something they considered of special attention is the time to organize lessons in this modality since "now you have no time or rest... weekends are no longer weekends because they believe that working from home you are always resting". This leads to "mental burnout" by all actors involved according to the participants.

In relation to parents and students, administrators indicated that they were not prepared to take on a new educational modality either. On the one hand, "parents are not prepared to help their children with their homework" was one of the difficulties expressed. On the other hand, being "digital natives, "neither were the students prepared to do schoolwork at a distance as indicated by the participants. Thus, they noted the difficulties 
for students and parents to understand the instructions sent through the various means used; and, many of them indicated that communication with students represents one of the greatest difficulties, stating that "the greatest challenge is to reach all students in the same way as you would do it in person." The latter is closely related to the concern of all members of the community to not only reach everyone but to "ensure the quality" of the teaching-learning process in this extraordinary context.

\section{Measures to face the pandemic}

Half of the administrators expressed their disagreement with the measures to cancel face-to-face classes until December of this year, with private and subsidized institutions having the strongest opposition to this decision made by the national government. Regarding the measures adopted by the institutions to mitigate this situation, the study indicates the main focus was to ensure the continuity of the educational process. In this context, $87 \%$ of educational institutions offered virtual classes considering the measures indicated by the government.

The school principals that indicated they were not teaching through digital technology presented different reasons. The lack of technological infrastructure, the lack of training in the use of digital tools, and temporary suspension of classes stood out as the main obstacles. Along the same lines, most administrators expressed that they were implementing these virtual classes for the first time, mediated by information and communication technologies. Of those who had been using virtual classes before the pandemic, mostly used technology as a complement to traditional face-to-face instructions (around 75\%).

Tabla 4: Virtual classes before and after quarantine

\begin{tabular}{|c|l|l|l|l|}
\hline \multirow{2}{*}{\multicolumn{2}{|c|}{}} & \multicolumn{2}{l}{$\begin{array}{l}\text { Teaching virtual classes based on the measures } \\
\text { adopted by the government }\end{array}$} \\
\cline { 2 - 5 } \multicolumn{2}{|c|}{} & Yes & No & Total \\
\hline $\begin{array}{l}\text { Virtual classes were } \\
\text { already being offered } \\
\text { before the pandemic }\end{array}$ & Yes & 25 & 1 & $\mathbf{2 6}$ \\
\cline { 2 - 5 } & No & 71 & 11 & $\mathbf{8 2}$ \\
\cline { 2 - 5 } & Total & $\mathbf{9 6}$ & $\mathbf{1 2}$ & $\mathbf{1 0 8}$ \\
\hline
\end{tabular}

Many of the school administrators also mentioned the need to provide support to all members of the community considering that "because of the pandemic everyone is very 'stressed' and in special need of emotional support." They mentioned that digital migration was being done "according to the possibilities" of institutions and community members because, as seen above, many do not have the optimal conditions to do so. They also mentioned the need to "adapt" to the circumstances, focus on the curriculum and "prioritize health". Along these lines, one of the participants reported the following:

We now ask parents to bring children's' books to school to check and thus try to get them to come and pay; in a week we will return them and, in this way, we will be evaluating the work done at home. We will begin taking the material for math and reading to their homes shortly taking 
into account the activities and taking the maximum necessary health precautions.

Some suggested measures to face this situation include to continue with virtual classes in the meantime as it is important to prioritize everyone's health. Some mentioned the need for the government to be able to "provide economic assistance to continue as well as the possibility of preparing printed materials to facilitate those who do not have assured connectivity," as well as to "provide teachers with computers and free internet for education so no one will have difficulty working." Another suggestion was for the government "to invest more on education, especially technology, infrastructure, and teacher training."

Another measure suggested was that "teachers return to the schools taking turns to coordinate their work from there, so that they could print the materials for those who don't have access to the internet. All teachers should return as soon as possible". Other suggestions included to "have theoretical classes online and labs and practical classes in person," or to "cancel classes for three months to return after the winter break," since at that time many community members felt that by then it would be possible to return to the classroom. However, after several months the situation is still not in a position to return to face-toface classes. Although there were a few that considered the cancellation of classes, most supported continuing education by all means possible, as one suggested:

We need to continue with virtual classes and recommend people to stop resisting change. Education cannot stop. That would be a set back and only because in a month and a half they are waiting for going back to in-person classes without doing any training or giving a chance to the marvelous opportunity which is the virtual experience. We all had fear in the beginning. But after a month and a half, to continue doing nothing is not acceptable. To me, this is an enriching experience and I had never given virtual classes before. I think it is great.

This quote takes us to the last category in our analysis, which is that of the opportunities presented by this sudden need to adapt to these unusual circumstances where the challenges and measures give way to considerable opportunities (Figure 1).

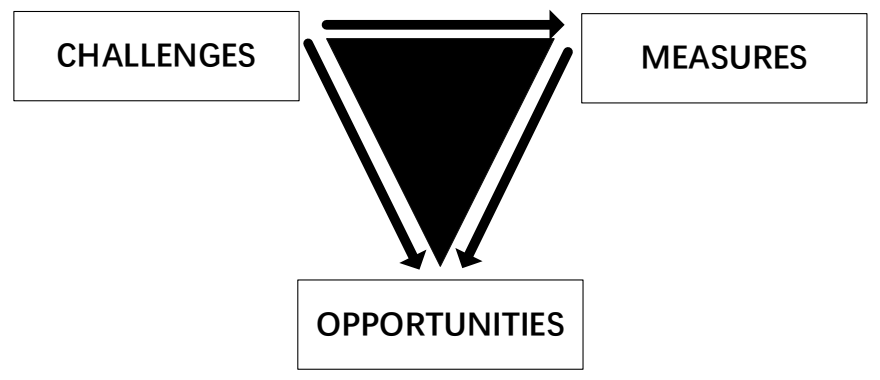

Figure 1. Challenges and measures giving way to opportunities 


\section{Opportunities presented by the situation}

Based on the difficulties and the measures adopted or suggested, educational administrators were able to identify some opportunities presented by this situation, first among which was to "explore the possibilities of distance teaching." Considering the subcategories identified, first was the opportunity for training. With respect to this aspect, participants noted that this situation "presents incredible opportunities to apply differentiated instruction... to encourage creativity on the part of the student and the teacher. "It is providing the opportunity "to grow in the use of technology and to access a world of possibilities."

Regarding this matter, they also noted that the opportunities include "training teachers to develop skills in all types of platforms," to "continue learning, continue growing and continue teaching," to "revise the evaluation system and promote collaborative work." One of them noted that "through training I now place more value in technology applications that can be used in virtual classes. We are learning to use computers with greater ease."

On the other hand, they also mentioned the opportunity to invest in infrastructure, especially technology but also on the buildings. One mentioned that this was a "brilliant opportunity for public institutions to have quality infrastructure for their students according to the needs, to be safe." Something also related to school organization had to do with the opportunities granted by teleworking. One participant noted that

Video communication, including videoconferencing, virtual meetings, webinars, etc. are neutralizing the distance effect and are fostering a greater participation in meetings or events in many social spheres. They also minimize costs and travelling expenses.

Some participants mentioned the opportunity to "get closer to families as they had to become closer partners in supporting students' learning. They mention the "opportunity to have more solidarity and strengthen values." Thus, many referred to the "opportunity to restructure the systems we have" in a way that allows us to "use technology to enhance the learning process," to "work together to improve the quality of education" and "create a collective awareness that will change the vision of education."

\section{DISCUSSION}

The right to education has been strongly affected by the current confinement regulations caused by COVID-19 (Cáceres-Muñoz et al., 2020). The maxim: the education system should guarantee equality of opportunities for all (Trujillo et al., 2020), has been challenged by school closure and technology-mediated learning. Similarly, the prolonged closure of schools has prompted researchers to question its efficacy at preventing the spread of the virus (Wang et al., 2020) as so far there is no real evidence of it preventing the spread (Viner et al., 2020). Within this context education has seen "the largest and quickest transformation of pedagogic and assessment practice ever seen" (Brammer \& Clark, 2020, p. 454). Moreover, these transformations were made to mitigate the negative effects that are now evident; loss of learning and human capital and diminished economic opportunities for students (World Bank Education, 2020) along with social and economic gaps in relation to access to technology (Álvarez et. Al, 2020; Armitage \& Nellums, 2020; Esposito \& Principi, 2020; Li \& Lalani, 2020; Lloyd, 2020; Vivanco-Saraguro, 2020). 
The present study considers three main aspects that portray the experience of school administrators in times of COVID-19; namely, challenges, opportunities and measures taken as a response of the quarantine regulation. Presently, the opportunities and challenges reflect two main views on education; the "re-imagination or a realignment of education... and the return to the 'old normal' to re-engage with all that went before" (Harris, 2020, p. 2). Thus, there are those who call for the redesign of the current educational system through the opportunities created by the pandemic. On the other hand, there are those who view the current situation as a challenge that will pass, and the emergency measures taken as means used only to mitigate the negative effects of school closures (Netolicky, 2020). Yet, there is no real consensus as to what changes can be made that will provide long term solutions to the lack of face-to-face instruction.

The study results indicate that administrators face challenges such as reducing their school staff and monthly salaries and providing reduced tuition costs in light of economic hardships caused by the pandemic affecting families and students. Although the roles of school administrators have not changed much, the pandemic has placed new pressures on administrators to engage in new solutions to ensure the continuity of the education process (StoneJohnson \& Miles, 2020). More than ever now, administrators need to be aware of the needs of their staff, students, and the broader school community. It is expected from administrators to be aware of their contexts, take the lead and make effective decisions, as well as, effect the most suitable strategies that they think could work within them (Netolicky, 2020).

Moreover, administrators confirmed that although teachers are acquainted with technology, they faced difficulties. This can be caused by the rapid change to virtual classrooms, lack of clear guidelines from the Ministry of education, and the increase of workload mentioned in the study. On this note, Tomei (2006) states that planning for online classes takes $14 \%$ more time than planning for traditional classes. Also, Johnson, Veletsianos \& Seaman, J. (2020) note that the primary areas where faculty and administrators identified a need for assistance is related to student support, greater access to online digital materials, and guidance for working from home. On the other hand, it is remarkable that administrators also reported that students and parents faced challenges with the use of ICT for educational purposes. Although "students were born in the age of modern digital technology" (Tzifopoulos, 2020, p. 4), there is still an important divide concerning the use of technology. Gomez (2020) discusses the "second digital gap" that refers to digital competence. That is, it is not enough to have access to technology, but also to be able to use technological devices by operating complex or advanced software tools which at times are necessary for learning (Gomez, 2020).

It can be noted that despite the efforts, administrators reported that the situation caused much stress in the school community. In this context, the situation is propitious for such reactions. At the same time, these difficulties faced by teachers, students and educational entities when trying to deal with virtual classes are also met by the lack of pedagogical and programmatic guidelines from government agencies and the continuous changes in terms of the implementation of new strategies (Soto-Córdova, 2020). The need for a plan or line of action in situations of adversity, such as the current one, is crucial within the institutions in such a way 
as to ensure not only the continuity of the educational process but also leadership on the part of educational managers (Hernández, 2020). In this case, as noted in the results, the main focus of guidelines received from government officials was the continuity of education, with such emergency measures focusing mainly on content rather than learning. On this note, Bozkurt and Sharma (2020 state "we should show our commitment to support our students, and to institute teaching and learning on the grounds of a pedagogy of care, not on purely didactic and insensitive grounds" (p. 4).

Among the main opportunities reported by school administrators we note the attitudes concerning digital migration to be the most common. The situation is seen as convenient to rethink new pedagogical designs and pertinent to explore and learn new strategies concerning distance education. Moreover, the change to distance education represents a new opportunity to work together towards a new goal; maintaining high quality education through technological delivery of classes. Digital technology for the purpose of communication and teacher training is also a good opportunity for the adoption of new means of learning for both administrators and teachers. As Azorín (2020, p. 1) notes "COVID-19 affords a golden opportunity to rethink what matters most in education." In this case, the learning is not only seen from the students and parents' point of view rather from the whole school community. Challenges and measures taken have forced administrators and teachers to depend on each other to learn faster and grow professionally. In this manner, as seen in the qualitative section, there is a call for collaborative learning among professionals to improve the delivery and the quality of education. A similar view on this is offered by Hargreaves and O'Connor (2018, p. 16), noting that "some aspects of collaborative professionalism, especially across schools, definitely benefit from creative uses of digital technology."

\section{CONCLUSION}

The results of this study show that at the beginning of the measures adopted by the government, educational institutions had many problems in the development of distance learning. The main difficulties reported by teachers and educational managers included aspects related to digital migration, such as limited access to the Internet and ICT, as well as poor training in its use by all members of the community, uncertainty about the situation and maintaining educational quality. In order to give continuity to the processes, the measures adopted by the institutions included adapting to the circumstances as much as possible and taking financial measures, among others. Despite the difficulties, educational administrators indicated that this situation, by bringing to light the differences that exist in society, is an excellent opportunity to rethink the educational system.

Therefore, it can be said that minimizing student desertion and preserving the quality of education represent the greatest challenges to the continuity of the educational process. These aspects demonstrate the need for greater and better access to educational technologies by the main educational actors in the country to guarantee equal academic opportunities (Trujillo et al., 2020; Azorín, 2020) and at the same time ensure that Paraguayan students have access "to a quality education, under equal conditions" (Juntos por la Educación, 2019 , p.11). In other words, the children of Paraguay have the right to access quality education, under equal conditions, regardless of the socioeconomic contexts of which they 
are part or the educational institution they attend (Juntos por la Educación, 2019). A follow-up study is planned for the end of the school year to take into account how the perspectives of the educational actors evolved during the year and how they evaluate the experience of digital migration.

Some limitations of this study include the limited sample that we were able to collect considering the pandemic situation which did not allow for a representative sample of educational administrators around the country. However, this study attempted to provide an insight into educational administrators' experiences regarding how institutions faced the measures adopted by the Paraguayan government during the first weeks of the pandemic. A follow-up study is planned for the end of de academic year to compare these perspectives to the ones that developed throughout this very exceptional school year. It will include both qualitative and quantitative components that will allow a more in-depth understanding of the impact of these measures on the Paraguayan educational system.

\section{REFERENCES}

Álvarez, H., et al. (2020). La educación en tiempo de coronavirus: Los sistemas educativos de América Latina y el Caribe ante COVID-19. Banco Interamericano de Desarrollo.

Armitage, R., \& Nellums, L. (2020). Considering inequalities in the school closure response to COVID-19. The Lancet Global Health, 8(5), e644. doi:10.1016s2214-109x(20)30116-9

Azorín, C. (2020). Beyond COVID-19 supernova. Is another education coming? Journal Of Professional Capital And Community. https://doi.org/10.1108/jpcc05-2020-0019.

Brammer, S., \& Clark, T. (2020). COVID-19 and Management Education: Reflections on Challenges, Opportunities, and Potential Futures. British Journal of Management, 31(3), 453-456. doi:10.1111/1467-8551.12425.

Cáceres-Muñoz J., Jiménez A. S., MartínSánchez M., (2020) Cierre de escuelas y desigualdad socioeducativa en tiempos del Covid-19. Una investigación exploratoria en clave internacional. Revista Internacional de Educación para la Justicia Social, 9(3e), 199-221. https:// doi.org/10.15366/riejs2020.9.3.011.

CEPAL, N. U. (2020). América Latina y el Caribe ante la pandemia del COVID-19: efectos económicos y sociales.

Cifuentes-Faura, J. (2020). Consecuencias en los Niños del Cierre de Escuelas por Covid-19: El papel del Gobierno, Profesores y Padres. Revista Internacional de Educación para la Justicia Social, 9(3).

CONES. (2020, Julio 29). Educación Superior del Paraguay en Tiempos de COVID-19 | Consejo Nacional de Educación Superior. CONES. Retrieved from: https:// bit.ly/388uwAu 
Esposito, S., \& Principi, N. (2020). School Closure During the Coronavirus Disease 2019 (COVID-19) Pandemic. JAMA Pediatrics. doi:10.1001/ jamapediatrics.2020.1892.

Gómez D. (2020) Jóvenes y desigualdad digital: las brechas de acceso, competencia y uso. Centro Reina Sofía sobre adolescencia y juventud.

Hargreaves, A. and O'Connor, M.T. (2018), Collaborative Professionalism: When Teaching Together Means Learning for all, Corwin Press, Thousand Oaks, CA.

Harris, A., (2020). COVID-19 - school leadership in crisis? Journal of Professional Capital and Community. Emerald Publishing Limited 2056-9548. DOI 10.1108/JPCC-06-2020-0045

Hernández, A. (2020). COVID-19: el efecto en la gestión educativa. Revista Latinoamericana De Investigación Social, 3(1), 37-41. Retrieved from https://bit. ly/3lrCb3f

Johnson, N., Veletsianos, G., \& Seaman, J. (2020). U.S. faculty and administrators' experiences and approaches in the early weeks of the COVID-19 pandemic. Online Learning, 24(2), 6-21. https://doi. org/10.24059/olj.v24i2.2285

Juntos por la Educación. (2019). Financiamiento público de la educación en el Paraguay: Notas para el debate y construcción de políticas públicas. Asunción. Retrieved from https://bit. ly $/ 3$ bct6Xm

Li, C., \& Lalani, F. (2020). The COVID-19 pandemic has changed education forever. This is how. Retrieved June 22, 2020 , from https://bit.ly/3dCiqkk

Lloyd, M. (2020). Desigualdades educativas y la brecha digital en tiempos de COVID-19. En H. Casanova Cardiel (Coord.), Educación y pandemia: una visión académica (pp. 115-121). Ciudad de México: Universidad Nacional Autónoma de México, Instituto de Investigaciones sobre la Universidad y la Educación.

MEC, Ministerio de Educación y Ciencias. (2020). Plan de Educación en Tiempos de Pandemia "Tu Escuela en Casa" [Ebook]. Asunción. Retrieved from https://bit.ly/2B8i0oJ

Monasterio, D. y Briceño, M. (2020). Educación mediada por las Tecnologías: Un desafío ante la coyuntura del Covid-19. Observador del Conocimiento, 5(1), 136-148.

Netolicky, D.M. (2020), "School leadership during a pandemic: navigating tensions", Journal of Professional Capital and Community. doi: 10.1108/JPCC-05-20200017.

R Core Team (2020). R: A language and environment for statistical computing. R Foundation for Statistical Computing, Vienna, Austria. URL https://www. R-project.org/.

Sanz, I.; Sainz G., J.; Capilla, A. (2020) Efectos de la Crisis del Coronavirus en la Educación Superior. Organización de Estados Iberoamericanos para la Educación, la Ciencia y la Cultura (OEI). Madrid, España. Retrieved from https:// bit.ly/3ipISkS

Soto-Córdova, I. (2020). La relación estudiante-docente en tiempos de cuarentena: desafíos y oportunidades del aprendizaje en entornos virtuales. Revista Saberes Educativos, (5), 70-99. Retrieved from https://bit.ly/31DEUGX

Stone-Johnson C., \& Miles J., (2020). Principal professionalism in the time of COVID-19. Journal of Professional Capital and Community. Emerald Publishing Limited 2056-9548. DOI 
10.1108/JPCC-05-2020-0020

Tomei, J. (2006). The impact of online learning on faculty load: Computing the ideal class size for online learning . Journal of Technology and Teacher Education, 14, 531-541.

Trujillo, F., Segura, A., Fernández, M., \& Jiménez, M. (2020). Escenarios de evaluación en el contexto de la pandemia por la COVID-19: la opinión del profesorado [Ebook]. Santillana. Retrieved from https://bit.ly/3iweQed

Tzifopoulos M. (2020). In the Shadow of Coronavirus: Distance education and digital literacy skills in Greece. International Journal of Social Science and Technology. 5(2).

UNESCO (2020a). "COVID-19 - Education is the bedrock of a just society in the postCOVID world." Retrieves from https://bit. ly/33rpD5f.

UNESCO (2020b). "Adverse consequences of school closure." Retrieved from https:// es.unesco.org/node/320395.

Viner, R., Russell, S., Croker, H., Packer, J., Ward, J., \& Stansfield, C. et al. (2020). School Closure and Management Practices During Coronavirus Outbreaks Including COVID-19: A Rapid Narrative Systematic Review. SSRN Electronic Journal. doi:10.2139/ssrn.3556648.

Vivanco-Saraguro, A. (2020). Teleducación en tiempos de COVID-19: brechas de desigualdad. CienciAmérica, [S.1.], v. 9, n. 2, p. 166-175. ISSN 1390-9592. doi: http://dx.doi.org/10.33210/ca.v9i2.307.

Wehrle Martínez, A. (2020). Educación en contextos de COVID-19: requerimientos mínimos para una educación a distancia [Blog]. Retrieved 22 August 2020, from https://www.observatorio.org.py/ especial/26.
World Bank Education (2020), "Guidance Note: Remote Learning and COVID-19", available at: https://bit.1y/3ju9T66 (accessed 23 August 2020)

Wozney, L., Venkatesh, V. y Abrami, P. (2006). Implementing computer technologies: Teachers' perceptions and practices. Journal of Technology and teacher education, 14(1), 173-207.

World Bank Group, 2020. COVID-19: Impacto en la educación, y respuestas de política pública. Resumen Ejecutivo. Recuperado de: https://bit.ly/301GYKZ

WHO. Coronavirus disease (COVID-19) advice for the public.(2020).

Retrieved June 11, 2020, from https://bit. ly/2YDDtyv.

Zhao, Y. (2020). COVID-19 as a catalyst for educational change. PROSPECTS. doi:10.1007/s11125-020-09477-y 